\title{
Flora da Paraíba, Brasil: Polygala L. (Polygalaceae) ${ }^{1}$
}

\author{
Victor Peçanha de Miranda Coelho², Maria de Fátima Agra ${ }^{2,4}$ e George Sidney Baracho ${ }^{3}$
}

Recebido em 25/09/2006. Aceito em 30/05/2007

\begin{abstract}
RESUMO - (Flora da Paraíba, Brasil: Polygala L. (Polygalaceae)). Neste trabalho apresenta-se o tratamento taxonômico do gênero Polygala L., como parte do projeto "Flora da Paraíba". Realizaram-se coletas e observações de campo para as identificações, descrições e ilustrações botânicas que foram efetuadas após estudos morfológicos, com o auxílio da bibliografia especializada, complementados pela análise de espécimes de herbários. O gênero Polygala está representado na Paraíba por 11 espécies: Polygala boliviensis A.W. Benn., P. cyparissias A. St.-Hil. \& Moq., P. galioides Poir., P. glochidiata Kunth, P. leptocaulis Torr. \& A. Gray, P. longicaulis Kunth, P. martiana A.W. Benn., P. paniculata L., P. sedoides A.W. Benn., P. spectabilis DC. e P. violacea Aubl. Com exceção de P. cyparissias, $P$. galioides, $P$. glochidiata, $P$. spectabilis e $P$. violacea, as demais espécies constituem novas referências para o Estado da Paraíba.
\end{abstract}

Palavras-chave: Polygalaceae, Polygala, Flora Paraibana, taxonomia, nordeste do Brasil

\begin{abstract}
Flora of Paraíba, Brazil: Polygala L. (Polygalaceae)). A taxonomic treatment of the genus Polygala L. was carried out as part of the project "Flora da Paraíba". Botanical identifications and illustrations were based on morphological studies supported by the literature and herbaria revisions, aided by field observations. Eleven species of Polygala were found in the state of Paraíba: Polygala boliviensis A.W. Benn., P. cyparissias A. St.-Hil. \& Moq., P. galioides Poir., P. glochidiata Kunth, P. leptocaulis Torr. \& A.Gray, P. longicaulis Kunth, P. martiana A.W. Benn., P. paniculata L., P. sedoides A.W. Benn., P. spectabilis DC. and P. violacea Aubl. Apart from P. cyparissias, $P$. galioides, $P$. glochidiata, $P$. spectabilis and $P$. violacea the other species are newly reported for the State of Paraíba.
\end{abstract}

Key words: Polygalaceae, Polygala, Flora Paraibana, taxonomy, Northeast Brazil

\section{Introdução}

Polygalaceae Hoffmannseg \& Link possui 22 gêneros e cerca de 1.000 espécies pertencentes a quatro tribos: Polygalae, Moutabeae, Carpolobeae (estritamente africana) e Xanthophylleae (indomalasiana), com ampla distribuição no mundo, excetuando-se a Nova Zelândia, zonas árticas e antárticas (Persson 2001; 2003), tendo as regiões temperadas quentes e tropicais como seus principais centros de diversidade (Furness \& Stafford 1995). Com base nos trabalhos de Marques (1980; 1989; 1996) e Marques \& Pastore (2006), estima-se que a família está representada no Brasil por sete gêneros e cerca de 250 espécies, dos quais o gênero Polygala é o mais representativo, com 140 táxons.

A posição sistemática da família sofreu algumas modificações desde que foi proposta. Hutchinson (1964) posicionou Polygalaceae na ordem Polygalales, juntamente com Krameriaceae, Trigoniaceae e Vochysiaceae. Cronquist (1988) aceitou a ordem proposta por Hutchinson (1964), à qual incorporou três outras famílias: Tremandraceae, Xanthophylaceae e Malpighiaceae. Atualmente, estudos filogenéticos, apoiados em dados moleculares, posicionaram Polygalaceae como o grupo basal da ordem Fabales, junto de Surianaceae, Quillajaceae e Fabaceae (Persson 2001; APG II 2003).

Polygala L. possui aproximadamente 350 espécies com ampla distribuição, principalmente nas regiões neotropicais (Persson 2003). Divisões infragenéricas têm sido propostas para o gênero (Bennet 1874; Chodat 1893; Paiva 1998), apoiadas na morfologia das flores, frutos, sementes e até na presença de nectários extraflorais. Eriksen (1993) utilizou dados morfológicos e anatômicos para sugerir que Polygala lato senso é polifilético. Entretanto, ressaltou a necessidade de um estudo mais amplo para o gênero. Persson (2001)

\footnotetext{
Parte da Monografia de Conclusão do Curso de bacharel em Ciências Biológicas do primeiro Autor

2 Universidade Federal da Paraíba, Laboratório de Tecnologia Farmacêutica Prof. Delby Fernandes Medeiros, C. Postal 5009, 58051-970 João Pessoa, PB, Brasil

3 Universidade de Pernambuco, Instituto de Ciências Biológicas, Laboratório de Biologia Vegetal, Departamento de Biologia, 50100-130 Recife, PE, Brasil

4 Autor para correspondência: agramf@1tf.ufpb.br
} 
sugeriu uma revisão na delimitação de Polygala, apoiado em dados moleculares.

O tratamento mais abrangente para Polygalaceae foi realizado por Bennett (1874), que descreveu oito gêneros e aproximadamente 150 espécies para a Flora Brasiliensis, e propôs uma divisão infragenérica para Polygala, baseada em caracteres artificiais, na qual dividiu o gênero em oito seções. Mais de um século depois, Marques (1979) realizou um tratamento para as espécies do gênero do Estado do Rio de Janeiro e, posteriormente, a revisão de Polygala sect. Polygala, Acanthocladus e Gymnospora para o Brasil (Marques 1984a; 1984b; 1988). Mais recentemente, foram realizados estudos taxonômicos com Polygala subg. Ligustrina (Marques, dados não publicados) e Polygala subg. Hebeclada (Aguiar, dados não publicados).

Outras informações relevantes sobre Polygalaceae são encontradas em floras ou flórulas regionais: Wurdack \& Smith (1971) e Lüdtke \& Miotto (2004), para o sul do Brasil; Marques $(1995 ;$ 1997), para o Pico das Almas, Bahia e flora do Estado do Rio de Janeiro, respectivamente; Martins \& Marques (1999), para a Reserva Ducke, Manaus; Marques \& Gomes (2002), para a flora fanerogâmica do Estado de São Paulo; e Miranda (2006), que elaborou uma listagem das espécies de Polygalaceae encontradas na Região Nordeste do Brasil. Também descrições de novas espécies para o país têm sido publicadas (Marques 1984c, 2003; Marques \& Guimarães 2003; Marques \& Pastore 2006).

Várias espécies de Polygala são de interesse farmacológico, dentre as quais destacam-se: Polygala cyparissias A. St.-Hil. \& Moq., com efeito antinociceptivo (Campos et al. 1997); P. paniculata L. e P. sabulosa A.W. Benn., como tripanossomicidas (Pizzolatti et al. 2002a); P. senega L. e P. tenuifolia Willd., como adjuvantes imunológicos (Estradaa et al. 2000; Nagai et al. 2001), e P. tenuifolia Willd., com potencial efeito antipsicótico (Shin et al. 2004). As espécies de Polygala caracterizam-se também pela presença de salicilato de metila, encontrado principalmente em suas raízes (Matos 2000), cumarinas (Hamburger et al. 1984; 1985; Pizzolatti et al. 2002b), derivados de pironas (Pizzolatti et al. 2000; Pizzolatti et al. 2004) e xantonas (Pinheiro et al. 1998; Jiang \& $\mathrm{Tu} 2002)$.

Estima-se a ocorrência de 20 espécies de Polygalaceae na Paraíba, sendo o gênero Polygala predominante, com cerca de $55 \%$ das espécies. As demais pertencem aos gêneros Bredemeyera,
Monnina e Securidaca (Coelho \& Agra, dados não publicados). Entretanto, as informações publicadas sobre Polygalaceae na Paraíba são raras e esporádicas, encontradas em uma revisão para Polygala sect. Polygala (Marques 1988), que refere a presença de $P$. cyparissias, $P$. galioides e $P$. glochidiata, como também, em três levantamentos florísticos (Marques 1979; Agra et al. 2004; Barbosa et al. 2005), que registraram a ocorrência de $P$. spectabilis DC. e $P$. violacea, em diferentes áreas do Estado. O presente trabalho teve como objetivo a realização do tratamento taxonômico de Polygala, como parte do Projeto Flora da Paraíba.

\section{Material e métodos}

Foram realizadas coletas de material botânico em diversos municípios da Paraíba, no período de maio/2003 a março/2006. Para os estudos morfológicos, utilizou-se material fresco e/ou fixado em $\mathrm{FAA}_{70}$, além de material herborizado pertencente aos acervos dos herbários Jayme Coelho de Moraes (EAN), Prof. Lauro Pires Xavier (JPB) e Prof. Dárdano de Andrade Lima (IPA). As identificações dos táxons foram feitas por meio de chaves e descrições encontradas na bibliografia (Bennett 1874; Wurdack \& Smith 1971; Marques 1979; 1988), complementadas pela análise de fotografias de tipos do herbário do New York Botanical Garden (NY) e do Smithsonian Institution (US), dos seguintes táxons: Polygala alfredi Chod., P. boliviensis A.W. Benn., P. galioides var. major A.W. Benn., P. leptocaulis Torr. \& A. Gray, P. longicaulis Kunth var. flavicoma, P. glochidiata Kunth f. leucantha S.F. Blake e P. spectabilis var. minor Chod. A classificação das folhas está de acordo com Rizzini (1977). As medidas das inflorescências foram tomadas incluindo-se as porções com frutos e cicatrizes. As informações sobre o hábito das plantas, cor das flores e frutos, fenologia, nome popular e distribuição geográfica foram obtidas, principalmente, das etiquetas das exsicatas, complementadas com dados da literatura, base de dados $\mathrm{W}^{3}$ TROPICOS e observações de campo. A análise morfológica do material botânico e a confecção das pranchas ilustrativas foram realizadas com o auxílio de estereomicroscópio e câmara-clara Zeiss. As abreviaturas dos autores dos táxons estão de acordo com Brummitt \& Powell (1992). O tratamento taxonômico seguiu o modelo proposto para a Flora da Paraíba (Nurit et al. 2005). 


\section{Resultados e discussão}

Polygala L., Sp. Pl. 2: 701-706. 1753.

Arbustos e ervas; raiz axial, ramificada, geralmente aromática. Caule folhoso a áfilo, muito ou pouco ramificado. Folhas simples, alternas, opostas ou verticiladas, sésseis ou pecioladas; lâmina inteira, membranácea a coriácea, glabra ou pilosa, variada na forma, tamanho e indumento. Inflorescências em racemos terminais ou axilares, panículas, espiciformes, fascículos umbeliformes ou subcapitados, densas ou laxas; 1 bráctea central e 2 bractéolas laterais diminutas, geralmente caducas. Flores bissexuadas, subactinomorfas ou zigomorfas, hipóginas. Cálice dialissépalo, 5 sépalas, persistentes ou caducas no fruto, dispostas em duas séries: três sépalas externas, 2 superiores, mais próximas, parcialmente soldadas ou não, 1 inferior livre; duas sépalas internas, glabras, maiores do que as externas, opostas, livres, petalóides, denominadas de alas. Corolas brancas, azuis, lilases, purpúreas, róseas, roxas ou violáceas; 3-(5) pétalas, soldadas parcialmente, sendo uma pétala modificada (carena), geralmente ungüiculada, com ápice cristado ou inteiro, cuculo sulcado no dorso ou não, recobrindo os órgãos reprodutores, e duas pétalas laterais, de formato e tamanho variados. Estames 6-8, formando uma bainha estaminal petalóide, soldada à carena e às pétalas laterais; anteras basifixas, poricidas. Ovário súpero, glabro, bicarpelar, bilocular, estilete terminal, ereto, uncinado, geniculado, com ou sem cavidade préestigmática, quando presente, em forma de coifa, hipocampiforme e cimbiforme, ereta ou oblíqua, ciliada ou não, com ou sem apêndice no ápice. Cápsula glabra, bilocular, unilocular por aborto, loculicida, alada ou não, com glândulas cróceas ao longo do septo ou não. Sementes 1-2, pêndulas, glabras ou pilosas, com ou sem carúncula, com ou sem apêndices.

Polygala é um gênero com cerca de 350 espécies, quase cosmopolita, com ampla distribuição mundial, exceto na Nova Zelândia e Polinésia, onde é introduzido (Persson 2003). De acordo com Marques \& Pastore (2006), o gênero está representado no Brasil por cerca de 110 espécies e 30 variedades.

Na Paraíba, Polygala está representado por 11 espécies, pertencentes a três subgêneros, Polygala subg. Polygala, Hebeclada e Ligustrina. Oito espécies pertencem a Polygala subg. Polygala (P. boliviensis A.W. Benn., P. cyparissias A. St.-Hil. $\&$ Moq., P. galioides Poir., P. glochidiata Kunth, P. leptocaulis Torr. \& A. Gray, P. longicaulis Kunth, $P$. paniculata L. e P. sedoides A.W. Benn.); duas pertencem ao subgênero Hebeclada ( $P$. martiana A.W. Benn. e P. violacea Aubl.); e apenas uma espécie, $P$. spectabilis DC., pertence ao subgênero Ligustrina. Estas espécies são encontradas nas diversas formações vegetais da Paraíba, desde as florestas úmidas (Floresta Atlântica e os Brejos de Altitude), até as áreas mais secas da Caatinga, no semiárido, como o Cariri Paraibano. Com exceção de Polygala cyparissias, P. galioides, $P$. glochidiata, $P$. spectabilis e $P$. violacea, as demais espécies constituem novas referências para a área de estudo. Em comparação com o número de espécies de Polygala registradas por Miranda (2006) para o nordeste brasileiro, cerca de $27,5 \%$ foram registradas para a Paraíba.

Chave para identificação das espécies de Polygala do Estado da Paraíba, Brasil

1. Plantas arbustivas; pecíolo com 2 glândulas opostas, na base; inflorescência com glândulas ao longo da raque e pedúnculo 10. $P$. spectabilis

1. Plantas herbáceas; pecíolo sem glândulas opostas, na base; inflorescência sem glândulas ao longo da raque

2. Carena de ápice inteiro

3. Caule com tricomas patentes; lâmina foliar elíptica a oval; pedicelo glabro; carena pilosa internamente 7. P. martiana

3. Caule com tricomas adpressos; lâmina foliar lanceolada; pedicelo pubérulo; carena glabra internamente 11. P. violacea

2. Carena de ápice cristado

4. Racemos cônico-cilíndricos; cuculo da carena sulcado no dorso; 6 estames 9. P. sedoides

4. Racemos espiciformes ou subcapitados; cuculo da carena não sulcado no dorso; 8 estames 5. Racemos subcapitados 
6. Cápsula oval, com glândulas cróceas ao longo do septo; sementes piramidais, sem apêndices.....

6. P. longicaulis

6. Cápsula orbicular, sem glândulas cróceas ao longo do septo; sementes esferóidepiriformes, com apêndices de 3,0-3,5 mm compr. 2. P. cyparissias

5. Racemos espiciformes

7. Ápice da cavidade pré-estigmática com apêndice cristado 3. P. galioides

7. Ápice da cavidade pré-estigmática sem apêndice cristado

8. Sementes com tricomas uncinados, sem apêndices 4. P. glochidiata

8. Sementes sem tricomas uncinados, com apêndices

9. Sementes com apêndices diminutos, ca. 0,1 mm compr. 5. P. leptocaulis

9. Sementes com apêndices de 0,5-0,7 mm compr.

10. Sementes cônicas, com uma coroa de tricomas na base 1. P. boliviensis

10. Sementes oblongas, sem uma coroa de tricomas na base 8. P. paniculata

1. Polygala boliviensis A.W. Benn., J. Bot. 17: 171. 1879.

Fig. 1-11

Erva 18-35 cm alt.; caule ramificado logo acima da base, piloso, tricomas falciformes. Folhas alternas na porção superior, verticiladas na porção basal, sésseis a curto-pecioladas, membranáceas, lâminas 8,0-20,0×1,0-2,0 mm, lineares a linear-lanceoladas, glabras, pontuadas, ápice agudo, base cuneada. Racemos espiciformes, laxifloros, 2,0-14,0 cm compr., raque e pedúnculo com tricomas falciformes; bráctea central 2,0×1,5 mm, ápice subulado, margem levemente serreada. Pedicelo 0,5-1,0 mm compr., glabro, pêndulo no fruto. Sépalas externas glabras; 2 superiores 1,5×0,5-0,6 mm, elípticas, soldadas no 1/4 basal, ápice agudo, base cuneada; 1 inferior $1,5 \times 1,0 \mathrm{~mm}$, oval, ápice subobtuso, base obtusa, 2 alas 3,5-4,0×1,5 mm, ovalelípticas, glabras, ápice subobtuso, base cuneada. Corola róseo-esbranquiçada a violácea, glabra; carena ca. 3,0 mm compr., ápice cristado, 8-lobulado, cuculo não sulcado no dorso; pétalas laterais $3,0 \times 1,0 \mathrm{~mm}$, irregularmente lanceoladas. Bainha estaminal ca. 2,0 mm compr., glabra; 8 estames, anteras obovais ou oblongas. Ovário $1,0 \times 0,5 \mathrm{~mm}$, oblongo; estilete uncinado; estigma globoso; cavidade pré-estigmática hipocampiforme, oblíqua, com tufo de tricomas no ápice, sem apêndice cristado. Cápsula 3,5-4,0×1,0-1,5 mm, oblonga, sem glândulas cróceas ao longo do septo, ápice emarginado, base irregularmente cuneada. Sementes 2,5-3,0 $\times 0,5 \mathrm{~mm}$, cônicas, base truncada, pilosas, tricomas curtos, não uncinados, e uma coroa de tricomas patentes na base; 2 apêndices longos, 0,5-0,7 mm compr., membranáceos, ca. 1/4 do comprimento da semente.

Polygala boliviensis foi referida por Adolfo (1966) e Foster (1958) para a Bolívia. No Brasil, Marques
(1988) referiu esta espécie, pelo seu sinônimo Polygala alfredi Chodat, para os Estados do Maranhão, Piauí, Ceará e Bahia. Na Paraíba, foi encontrada no semiárido, ocorrendo em diferentes microrregiões, habitando ambientes secos, com solos argilosos, arenosos e pedregosos, próximo a afloramentos rochosos.

Material examinado: BRASIL. Paraíba: São José da Mata, Faz. Pedro da Costa Agra, $7^{\circ} 46^{\prime}$ S, 3552'W, VI/1995, fl., fr., M.F. Agra et al. 3359 (JPB); V/2004, fl., fr., M.F. Agra et al. 6137 (JPB); São João do Cariri, IV/1994, fl., fr., M.F. Agra et al. 3002 (JPB); Araruna, na base da Pedra da Boca, $7^{\circ} 18$ '16"S, $34^{\circ} 56^{\prime} 28^{\prime \prime} \mathrm{W}, \mathrm{VIII} / 2005$, fl., fr., M.F. Agra \& V. Coelho 6512 (JPB).

2. Polygala cyparissias A. St.-Hil. \& Moq., Mem. Mus. Hist. Nat. 17: 368. 1828.

Fig. 12-21

Erva 15-35 cm alt.; caule ramificado desde a base, glabro. Folhas alterno-espiraladas, sésseis, carnosas, lâminas 8,0-12,0×0,5 mm, lineares, glabras, ápice mucronulado, base cuneada. Racemos subcapitados, densifloros, 1,3-5,0 cm compr., raque e pedúnculo glabros; bráctea central ca. 2,0×1,5 mm, ápice subulado, margem lisa. Pedicelo 2,0-2,2 mm compr., glabro. Sépalas externas glabras; 2 superiores $3,5 \times 1,0 \mathrm{~mm}$, lanceoladas, soldadas no $1 / 4$ basal, ápice levemente subulado, base obtusa; 1 inferior $2,5 \times 1,0 \mathrm{~mm}$, oval, ápice agudo-apiculado, base obtusa; 2 alas 3,5-4,0× 1,0-1,5 mm, oblongas ou elípticas, glabras, ápice mucronulado, base cuneada. Corola branca, glabra; carena ca. 2,5×1,0 mm, ápice cristado, 8-lobulado, cuculo evidente; pétalas laterais $2,5-3,5 \times 1,0 \mathrm{~mm}$, obovais. Bainha estaminal 3,0 mm compr., pilosa no dorso; 8 estames, anteras oblongas. Ovário 1,0×0,5 mm, oval; estilete ereto; estigma globoso; cavidade pré- 
estigmática em forma de coifa, levemente oblíqua, ciliada. Cápsula 2,0-4,0×1,5-3,5 mm, orbicular, sem glândulas cróceas ao longo do septo, ápice obtuso. Sementes 1,5-2,0×1,0-1,5 mm, esferóide-piriformes, arredondadas na base, pilosas, tricomas hialinos, não uncinados; 2 apêndices longos, 3,0-3,5 mm compr., não membranáceos, projetados ao longo da semente e curvados no ápice.

De acordo com Marques (1988), Polygala cyparissias é uma espécie encontrada no Brasil, Uruguai e Argentina. No Brasil, ocorre desde o nordeste até o sul. Na Paraíba, é encontrada em ambientes de vegetação pioneira, com solos arenosos.

Material examinado: BRASIL. Paraíba: Lucena, XI/1980, fl., fr., O.T. Moura 71 (JPB); Cabedelo, I/1987, fl., L.P. Félix \& J.V. Dornelas s.n. (EAN 1267); Praia do Poço, $7^{\circ} 57^{\prime} \mathrm{S}, 34^{\circ} 53^{\prime} \mathrm{W}, \mathrm{XI} / 1994$, fl., fr., M.F. Agra \& M. Luceño 3498 (JPB).

\section{Polygala galioides Poir., Encycl. 5: 503. 1804.}

\section{Fig. 22-29}

Erva ca. $20 \mathrm{~cm}$ alt.; caule tortuoso, simples ou ramificado; ramos angulosos, glabros. Folhas verticiladas, algumas alternas na porção superior, sésseis, membranáceas, lâminas 6,0-12,0×2,0-3,0 mm, elípticas, glabras, pontuadas, ápice mucronulado, base cuneada. Racemos espiciformes, densifloros ou laxifloros, 1,5-6,0 cm compr., raque e pedúnculo glabros; bráctea central ca. 1,0 mm compr., ápice subulado, margem lisa. Pedicelo ca. 0,5 mm compr., glabro, pêndulo no fruto. Sépalas externas glabras, com manchas cróceas basais a centro-basais; 2 superiores 0,5-0,8 $\times 0,3 \mathrm{~mm}$, lanceoladas, soldadas no $1 / 4$ basal, ápice agudo, base cuneada; 1 inferior 1,0-1,2× 0,5-0,7 mm, oval, ápice e base obtusos; 2 alas $1,2 \times 0,8 \mathrm{~mm}$, ovais, glabras, ápice obtuso, base ungüiculada. Corola lilás, glabra; carena ca. 1,4-1,5 mm compr., ápice cristado, 8-lobulado, cuculo não sulcado no dorso; pétalas laterais ca. 1,0 mm compr., obovais. Bainha estaminal ca. 1,0 mm compr., glabra; 8 estames, anteras oblongas. Ovário 1,0×1,0 mm, oval-elíptico; estilete uncinado; estigma globoso; cavidade préestigmática hipocampiforme, oblíqua, provida de apêndice cristado com um tufo de tricomas no ápice. Cápsula 1,0-1,2×1,0 mm, orbicular, sem glândulas cróceas ao longo do septo, ápice obtuso, levemente emarginado, base obtusa. Sementes $1,0 \times 0,5 \mathrm{~mm}$, oblongas, base arredondada, seríceas, tricomas hialinos, adpressos, não uncinados; 2 apêndices patentes, ca. 0,6 mm compr., membranáceos, alcançando $3 / 4$ do comprimento da semente.
Polygala galioides é uma espécie da América do Sul, com distribuição nas Guianas e no Brasil, onde foi registrada para os Estados de Roraima, Amapá, Paraíba, Pernambuco, Minas Gerais, Mato Grosso e Goiás (Marques 1988). Na Paraíba, foi encontrada em áreas de Floresta Atlântica e Brejos de Altitude, ocorrendo em solos humosos e arenosos úmidos.

Material examinado: BRASIL. Paraíba: Santa Rita,VI/1983, fl., fr., L. Xavier Filho s.n. (JPB 5541); Mata Redonda, IX/1954, fl., J.I.A. Falcão et al. 1111 (IPA); Areia, IX/1944, fl., J.C. Morais 159 (EAN).

4. Polygala glochidiata Kunth, in Humb., Bonpl. \& Kunth, Nov. Gen. Sp. 5: 400. 1823.

Fig. 30-38

Erva $15-30 \mathrm{~cm}$ alt.; caule ramificado logo acima da base; ramos pilosos, tricomas glandulares, hialinos. Folhas alternas na porção superior, verticiladas na porção basal, sésseis, subcarnosas, lâminas 5,0-12,0× 0,5-0,7 mm, lanceoladas, tricomas glandulares em ambas as faces, ápice agudo a acuminado, base cuneada. Racemos espiciformes, laxifloros, 2,5-1,0 cm compr., raque e pedúnculo glabros; bráctea central ca. 1,0 mm compr., ápice agudo, margem levemente serreada. Pedicelo ca. 1,0 mm compr., glabro, pêndulo no fruto. Sépalas externas glabras; 2 superiores $1,0 \times 0,5 \mathrm{~mm}$, elípticas, livres entre si, ápice agudo, base cuneada; 1 inferior, $1,0-1,5 \times 0,5 \mathrm{~mm}$, oval, ápice agudo, base obtusa; 2 alas 2,0-2,5×1,0-1,1 mm, ovais, glabras, ápice e base obtusos. Corola rósea, glabra; carena ca. 2,5 mm compr., ápice cristado, 8-lobulado, cuculo não sulcado no dorso; pétalas laterais 1,5-2,0 mm compr., rômbico-elípticas, ápice irregular. Bainha estaminal ca. 1,0 mm compr., glabra; 8 estames, anteras ovais. Ovário ca. 1,0×0,5 mm, elíptico a oboval; estilete uncinado; estigma globoso; cavidade pré-estigmática cimbiforme, oblíqua, com tufo de tricomas no ápice, sem apêndice cristado. Cápsula ca. 1,6×1,0 mm, oboval, sem glândulas cróceas ao longo do septo, ápice e base obtusos. Sementes ca. 1,0×0,8 mm, obovais, base arredondada, pilosas, tricomas uncinados; sem apêndices.

Polygala glochidiata é uma espécie com ampla distribuição, encontrada do sul dos Estados Unidos, América Central (México, Cuba e Guatemala) e na América do Sul (Colômbia, Venezuela, Brasil e Argentina). No Brasil, foi registrada por Marques (1988) para todas as regiões do país. Na Paraíba, foi encontrada em áreas de Floresta Atlântica e Caatinga, ocorrendo em solos arenosos, úmidos e pedregosos. 


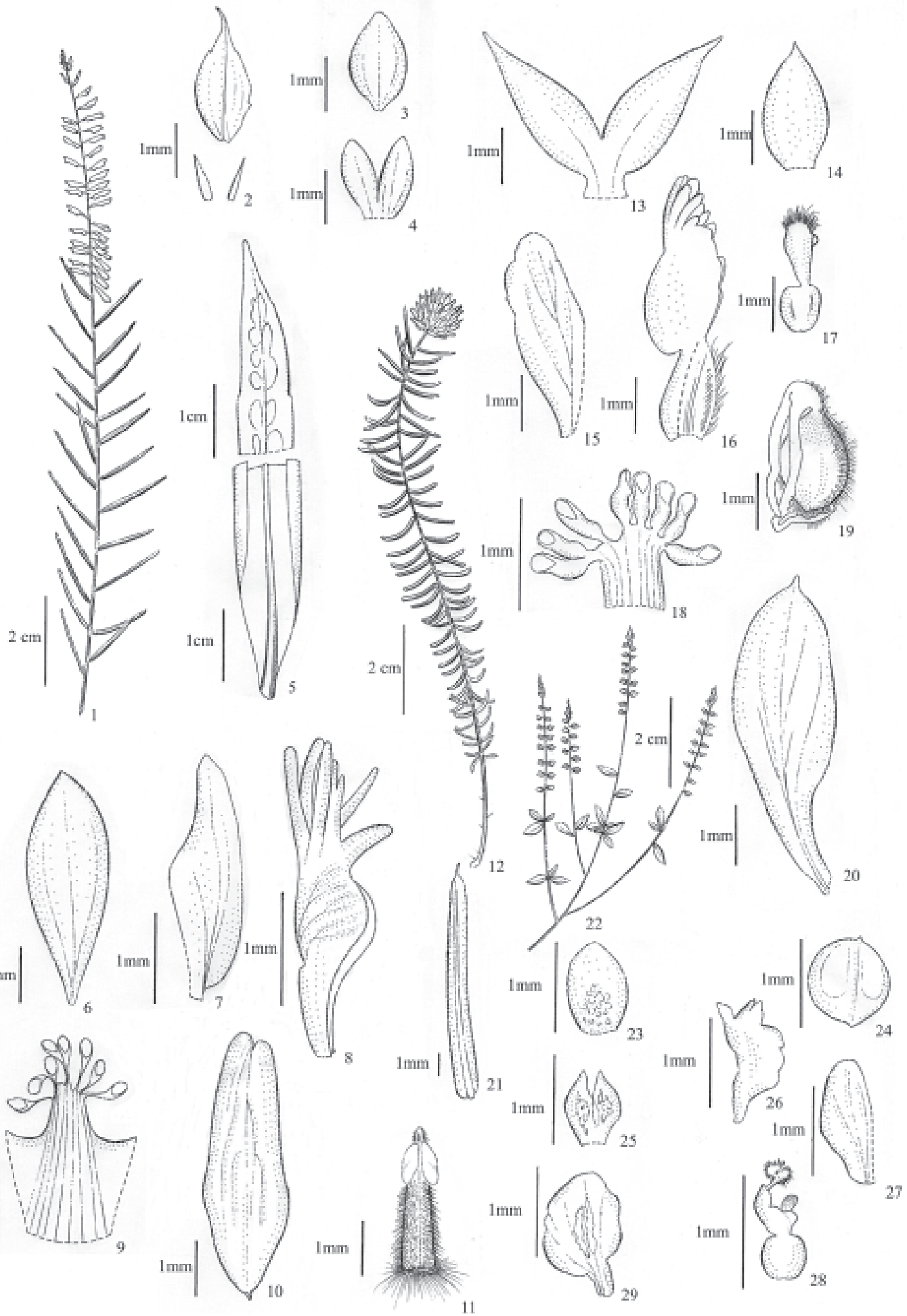

Figuras 1-11. Polygala boliviensis A.W. Benn. (Agra \& Coelho 6512): 1. Ramo. 2. Bráctea e bractéolas. 3. Sépala externa inferior. 4. Sépalas externas superiores. 5. Folha isolada. 6. Ala isolada. 7. Pétala lateral. 8. Carena. 9. Androceu. 10. Fruto. 11. Semente. Figuras 12-21. P. cyparissias A. St.-Hil. \& Moq. (Agra \& Luceño 3498): 12. Ramo. 13. Sépalas externas superiores. 14. Sépala externa inferior. 15. Pétala lateral. 16. Carena. 17. Gineceu. 18. Androceu. 19. Semente. 20. Ala isolada. 21. Folha. Figuras 22-29. P. galioides Poir. (Falcão et al. 1111): 22. Ramos. 23. Sépala externa inferior. 24. Fruto. 25. Sépalas externas superiores. 26. Carena. 27. Pétala lateral. 28. Gineceu. 29. Ala isolada. 
Material examinado: BRASIL. Paraíba: Mamanguape, VIII/1988, fl., fr., L.P. Félix \& C.A.B. Miranda s.n. (JPB 8446); Pocinhos,VI/72, fl., fr., Izomil s.n. (JPB 3255); estrada entre Serra Branca e Cabaceiras, XI/2002, fl., fr., M.F. Agra et al. 5799 (JPB).

5. Polygala leptocaulis Torr. \& A. Gray, Fl. N. Amer. 1: 130.1838.

Fig. 39-47

Erva 30-45 cm alt.; caule ramificado, glabro. Folhas alternas, curto-pecioladas, subcarnosas, lâminas 10,0-20,0×1,0 mm, linear-lanceoladas, glabras, ápice agudo-acuminado, base atenuada. Racemos espiciformes, laxifloros, 2,0-6,0 cm compr., raque e pedúnculo glabros; bráctea central ca. 1,0 mm compr., ápice subulado, margem levemente serreada. Pedicelo 0,5-1,0 mm compr., glabro, pêndulo no fruto. Sépalas externas glabras; 2 superiores $0,7-1,0 \times 0,5 \mathrm{~mm}$, oblongolanceoladas, livres entre si, levemente côncavas, 2 glândulas basais, ápice subobtuso, base obtusa; 1 inferior $0,9-1,0 \times 0,5 \mathrm{~mm}$, oval, ápice obtuso, base truncada; 2 alas 2,0×0,7-0,8 mm, oboval-oblongas, glabras, ápice obtuso, base cuneada. Corola rósea, lilás ou violácea, glabra; carena ca. 1,5 mm compr., ápice cristado, 8-lobulado, cuculo não sulcado no dorso; pétalas laterais $1,5 \times 0,5 \mathrm{~mm}$, irregularmente elípticas. Bainha estaminal ca. 1,0 mm compr., glabra; 8 estames, anteras obovais. Ovário ca. 0,5 mm compr., orbicular; estilete uncinado; estigma globoso; cavidade préestigmática em forma de coifa, oblíqua, com tufo de tricomas no ápice, sem apêndice cristado. Cápsula 1,0-2,0×0,5-1,0 mm, oval a oblonga, sem glândulas cróceas ao longo do septo, ápice levemente emarginado. Sementes $1,0 \times 0,5 \mathrm{~mm}$, oblongas, arredondadas na base, pilosas, tricomas curtos, hialinos, não uncinados; 2 apêndices diminutos, ca. $0,1 \mathrm{~mm}$ compr., membranáceos.

Espécie com distribuição nos Estados Unidos, América Central (México e Cuba) e América do Sul (Colômbia, Venezuela, Bolívia, Brasil e Argentina). No Brasil, Polygala leptocaulis foi encontrada em todas as regiões do país (Marques 1988). Na Paraíba, a espécie foi coletada em áreas de remanescentes de Floresta Atlântica, habitando solos humosos.

Material examinado: BRASIL. Paraíba: Mamanguape, Sema I, III/1990, fl., L.P. Félix \& E.S. Santana 2801 (JPB); Baía da Traição, IX/1990, fl., fr., O.T. Moura 503 (JPB).
6. Polygala longicaulis Kunth, in Humb., Bonpl. \& Kunth, Nov. Gen. Sp. 5: 396. 1823.

Fig. 48-56

Erva $15-40 \mathrm{~cm}$ alt.; caule levemente estriado, pouco ramificado, glabro. Folhas alternas, sésseis a curtopecioladas, carnosas, lâminas 8,0-30,0× 1,5-6,0 mm, lanceoladas ou lineares, glabras, ápice agudomucronulado, base cuneada. Racemos subcapitados, densifloros, 1,0-3,0 cm compr., raque e pedúnculo glabros; bráctea central $2,0 \times 0,5 \mathrm{~mm}$, triangularlanceolada, ápice ligulado, margem serreada. Pedicelo 2,0-3,0 mm compr., glabro. Sépalas externas glabras, 2 superiores 1,0-2,0 mm compr., elípticas a ovais, soldadas no 1/4 basal, com glândulas cróceas, ápice agudoacuminado, base truncada; 1 inferior 1,0-2,0 mm compr., elíptica a oboval, ápice agudo mucronulado, base truncada; 2 alas 4,5-5,7×2,0-2,5 mm, lanceoladas, glabras, ápice cuspidado, base cuneada. Corola rósea, lilás a alvacenta, glabra; carena 3,0-6,0 mm compr., ápice cristado, 6-lobulada, cuculo no terço superior, com glândulas no dorso; pétalas laterais 3,5-5,0 mm compr., lineares, ápice agudo. Bainha estaminal 3,0-4,5 mm compr., glabra, soldada em toda sua extensão; 8 estames, anteras obovais. Ovário 1,0-1,5×0,5-1,0 mm, oblongo a oboval; estilete ereto; estigma globoso; cavidade pré-estigmática em forma de coifa, ereta, com tufo de tricomas no ápice, sem apêndice cristado. Cápsula 3,0×2,0 mm, oval a oblonga, com glândulas cróceas ao longo do septo, ápice levemente emarginado. Sementes ca. 2,0 mm compr., piramidais, base truncada, pilosas, com tricomas curtos, não uncinados, e uma coroa de tricomas patentes na base; sem apêndices.

Polygala longicaulis é uma espécie que ocorre no México, Paraguai e Brasil, onde foi registrada por Marques (1988) para os para todas as regiões do país. Na Paraíba, foi encontrada em ambientes de vegetação pioneira e em áreas de Floresta Atlântica, ocorrendo em solos arenosos, pedregosos e humosos.

Material examinado: BRASIL. Paraíba: Mangabeira, XI/1991, fl., fr., O.T. Moura 710 (JPB); Santa Rita, IX/1987, fl., fr., M.F. Agra \& L.M. Batista s.n. (JPB 16698); em VI/1996, fl., fr., M.R. Barbosa 1526 (JPB); em 757'S, 3500'W, XI/1994, fl., fr., M.F. Agra \& Góis 3615 (JPB); IX/2005, fl., fr., M.F. Agra \& V. Coelho 6664 (JPB); Mamanguape, VII/1989, fl., fr., L.P. Félix \& E.S. Santana 2221 (JPB); V/1959, fl., J.C. de Morais s.n. (EAN 2163); Divisa de Itambé com Pedras de Fogo, XI/1951, fl., Ducke \& A. Lima 53 (IPA); Mata Redonda, IX/1954, fl., fr., J.I.A. Falcão et al. 1107 (IPA). 


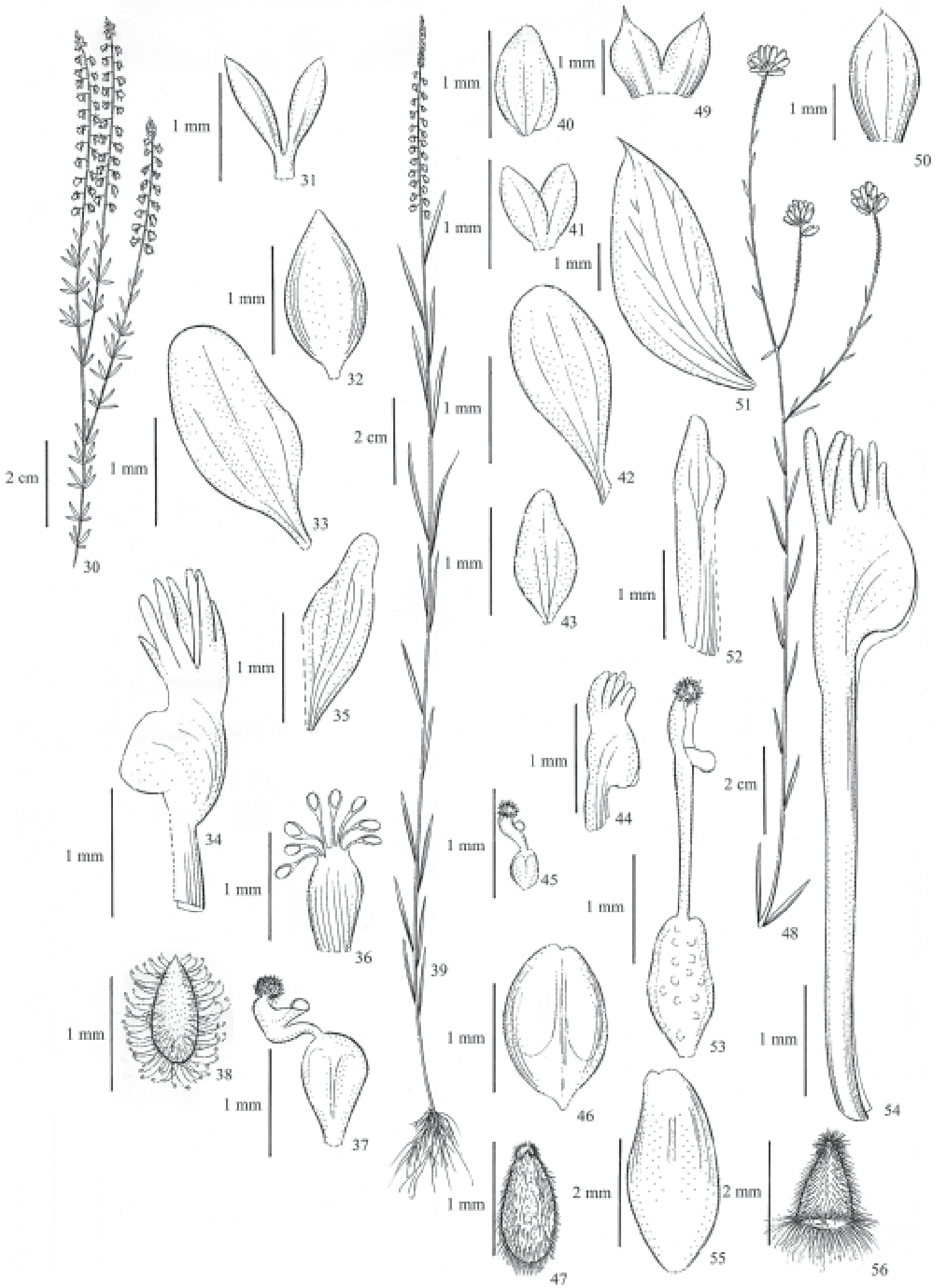

Figuras 30-38. Polygala glochidiata Kunth (Agra et al. 5799): 30. Ramo. 31. Sépalas externas superiores. 32. Sépala externa inferior. 33. Ala isolada. 34. Carena. 35. Pétala lateral. 36. Androceu. 37. Gineceu. 38. Semente. Figuras 39-47. P. leptocaulis Torr. \& A. Gray (Félix \& Santana 2801): 39. Hábito. 40. Sépala externa inferior. 41. Sépalas externas superiores. 42. Ala isolada. 43. Pétala lateral. 44. Carena. 45. Gineceu. 46. Fruto. 47. Semente. Figuras 48-56. P. longicaulis Kunth (Agra \& Coelho 6664): 48. Ramo. 49. Sépalas externas superiores. 50. Sépala externa inferior. 51. Ala isolada. 52. Pétala lateral. 53. Gineceu. 54. Carena. 55. Fruto. 56. Semente. 
7. Polygala martiana A.W. Benn., in Mart., Fl. bras. 13(3): 13, t. 6, t. 30a, f. 11. 1874.

Fig. 57-65

Erva 30-40 cm alt.; caule e ramos pilosos, tricomas patentes, hialinos e curtos, falciformes. Folhas alternas, membranáceas; pecíolo 1,0-2,0× $0,5 \mathrm{~mm}$, cilíndrico, com tricomas patentes, hialinos; lâminas 30,0-45,0×16,0-25,0 mm, elípticas a ovais, margens ciliadas, glabras na face adaxial, pubérulas na face abaxial, ápice agudo, base obtusa. Racemos espiciformes, densifloros, 2,0-5,0 cm compr., raque e pedúnculo densamente pilosos, tricomas patentes, hialinos; bráctea central ca. 1,0-1,5 mm compr., lanceolada, ápice subulado, margem ciliada. Pedicelo 1,0-2,0 mm compr., glabro, pêndulo no fruto. Sépalas externas glabras, glanduloso-ciliadas; 2 superiores $2,0 \times 1,0 \mathrm{~mm}$, soldadas parcialmente, levemente côncavas, ápice agudo; 1 inferior $3,0 \times 1,0 \mathrm{~mm}$, lanceolada a elíptica, côncava, ápice agudo, base cuneada; 2 alas 4,0-4,5×3,5 mm, suborbiculares, glabras, ápice obtuso-arredondado, base subobtusa. Corola rósea a purpúrea; carena 3,0-3,5 mm compr., pilosa internamente, tricomas patentes, hialinos, ápice inteiro, emarginado, cuculo não sulcado no dorso; pétalas laterais 3,0-3,5 $\mathrm{mm}$ compr., espatuladas, pilosas, tricomas patentes, hialinos. Bainha estaminal ca. 2,0 mm compr., pilosa, tricomas similares aos das pétalas laterais; 8 estames, anteras oblongas. Ovário 1,0-1,5×1,0 mm, oval a sub-retangular; estilete uncinado ou geniculado; estigma subgloboso, com tufo de tricomas na porção inferior; sem cavidade préestigmática. Cápsula 4,0-4,5×2,5-3,0 mm, oval a subretangular, sem glândulas cróceas ao longo do septo, ápice emarginado, base obtusa. Sementes $3,5 \times 1,5 \mathrm{~mm}$, oblongas, base sub-retangular, seríceas, tricomas adpressos, não uncinados; carúncula com dois apêndices córneos na base.

De acordo com Marques (1979), Polygala martiana é uma espécie provavelmente endêmica do Brasil, com registro para todas as regiões do país. $\mathrm{Na}$ Paraíba, a espécie foi encontrada em áreas de Floresta Atlântica, ocorrendo em solos humosos, arenosos, pedregosos e em terrenos abandonados, podendo ser considerada uma planta ruderal.

Material examinado: BRASIL. Paraíba: João Pessoa, Campus I UFPB, VII/1978, fl., M.F. Agra 32 (JPB); III/1994, fl., fr., E. Locatelli 8 (JPB); Praia de Jacarapé, V/1984, O.T. Moura 221 (JPB); Sapé, I/1978, fl., M.F. Agra 34 (JPB); Mamanguape, Sema II, V/1989, fl., L.P. Félix s.n. (EAN 14667).
8. Polygala paniculata L., Syst. Nat. 2: 1154. 1759. Fig. 66-74

Erva 10-40 cm alt.; caule ramificado logo acima da base ou na porção superior, piloso, tricomas simples glandulares. Folhas alternas, sésseis a curto-pecioladas, membranáceas, lâminas 8,0-18,0×1,5-3,0 mm, lineares a lanceoladas, glabras, ápice agudomucronulado, base cuneada. Racemos espiciformes, laxifloros, 1,0-4,0 cm compr.; raque e pedúnculo cilíndricos ou angulosos, pilosos, tricomas glandulares; bráctea central ca. 0,8 mm compr., lanceolada, ápice apiculado. Pedicelo 0,5-0,7 mm compr., glabro, pêndulo no fruto. Sépalas externas glabras, pontuadoglandulosas; 2 superiores $1,0 \times 0,5 \mathrm{~mm}$, elípticas, soldadas no 1/4 basal, ápice agudo, base cuneada; 1 inferior 1,0×1,0 mm, oval, ápice obtuso, base obtusa; 2 alas 2,0-2,5×0,7-1,0 mm, oblongo-lanceoladas, glabras, ápice obtuso, base cuneada. Corola branca, glabra; carena ca. 2,0 mm compr., ápice cristado, 8-lobulado, cuculo não sulcado no dorso; pétalas laterais ca. 2,0 mm compr., lanceoladas. Bainha estaminal ca. 1,0 mm compr., glabra; 8 estames, anteras obovais. Ovário ca. $0,5 \mathrm{~mm}$ compr., orbicular; estilete uncinado; estigma globoso; cavidade pré-estigmática hipocampiforme, oblíqua, com tufo de tricomas no ápice, sem apêndice cristado. Cápsula 1,5-2,0×1,0 mm, orbicular, sem glândulas cróceas ao longo do septo, ápice emarginado. Sementes 1,5×0,5-0,7 mm, oblongas, rotundas na base, pubérulas, tricomas hialinos, não uncinados, sem coroa de tricomas; apêndices 2, 0,5-0,7 mm compr., membranáceos, ca. 1/2 do comprimento da semente.

De acordo com Marques (1988), Polygala paniculata é uma espécie com distribuição neotropical, encontrada no sul da América do Norte, América Central e América do Sul. No Brasil, foi registrada para todas as regiões do país. Na Paraíba, foi encontrada em áreas de Floresta Atlântica e Brejos de Altitude, ocorrendo em solos arenosos e humosos.

Material examinado: BRASIL. Paraíba: Areia, CCA,VI/1986, fl., fr., L.P. Félix \& J.V. Dornelas s.n. (50057 IPA); Santa Rita, V/1992, fl., fr., M.F. Agra 1881 (JPB).

9. Polygala sedoides A.W. Benn., in Mart., Fl. bras. 13(3): 27-28, t. 10, f. 3. 1874.

Fig. $75-83$

Erva 2,5-5,0 cm alt.; caule com ramos bifurcando-se no mesmo ponto de origem das inflorescências, glabros. Folhas alternas, sésseis, subcarnosas, lâminas 2,1-2,5×ca. 0,5 mm, lineares, glabras, ápice 

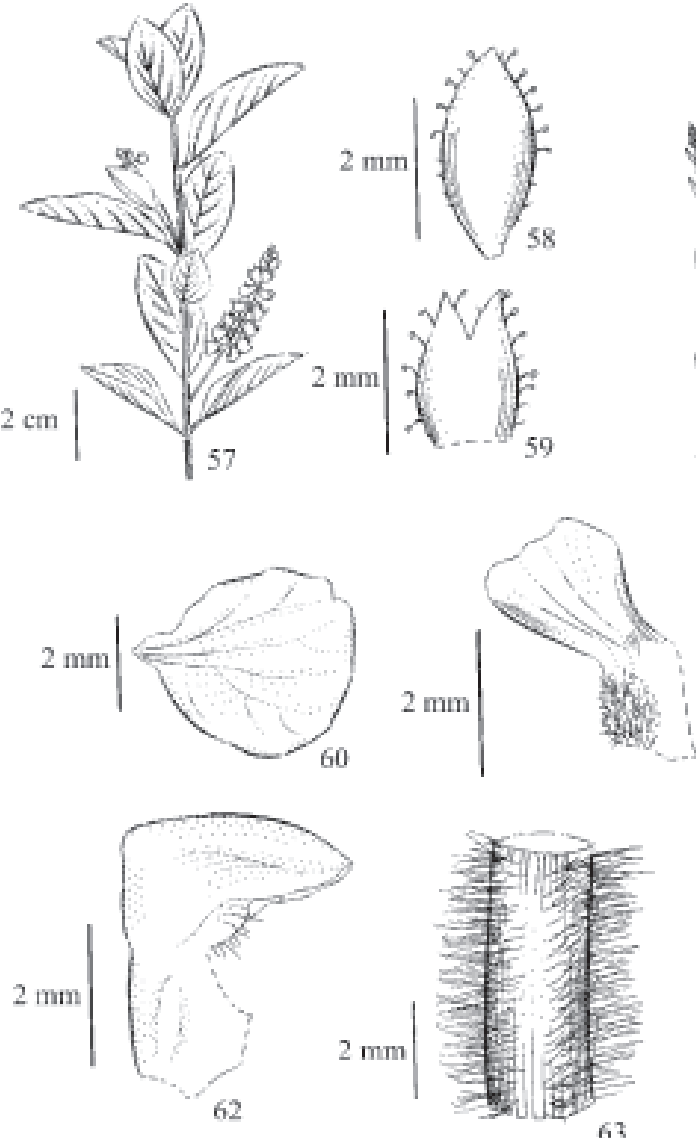

6I
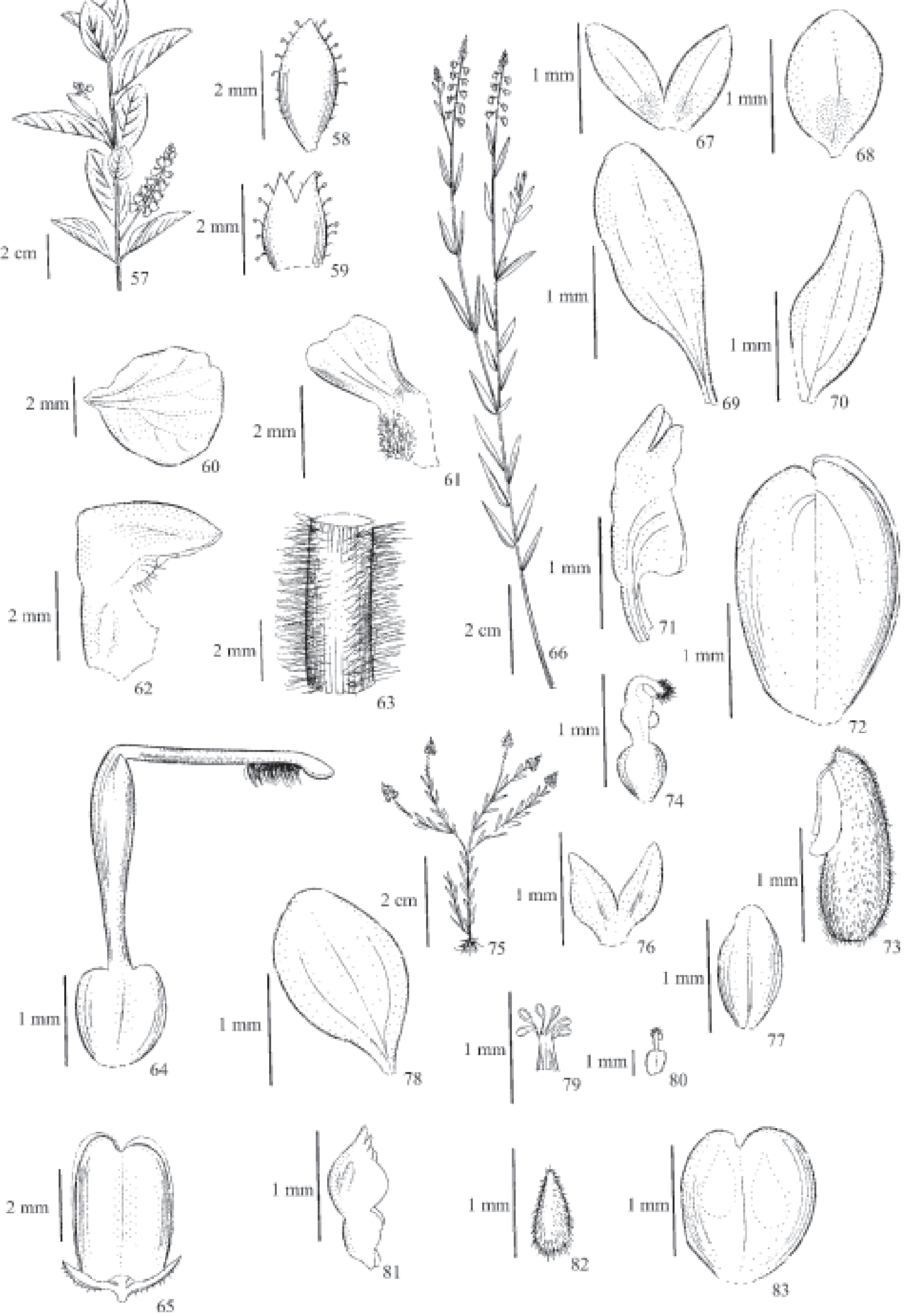

Figuras 57-65. Polygala martiana A.W. Benn. (Agra 32): 57. Ramo. 58. Sépala externa inferior. 59. Sépalas externas superiores. 60. Ala isolada. 61. Pétala lateral. 62. Carena. 63. Indumento do caule. 64. Gineceu. 65. Fruto. Figuras 66-74. P. paniculata L. (Agra 1881): 66. Ramo. 67. Sépalas externas superiores. 68. Sépala externa inferior. 69. Ala isolada. 70. Pétala lateral. 71. Carena. 72. Fruto. 73. Semente. 74. Gineceu. Figuras 75-83. P. sedoides A.W. Benn. (Moura 787): 75. Hábito. 76. Sépalas externas superiores. 77. Sépala externa inferior. 78. Ala isolada. 79. Androceu. 80. Gineceu. 81. Carena. 82. Semente. 83. Fruto. 
agudo, base cuneada. Racemos cônico-cilíndricos, densifloros, 0,4-1,3 cm compr., raque e pedúnculo glabros; bráctea central ca. 0,6-1,0 mm compr., lanceolada. Pedicelos $<0,5 \mathrm{~mm}$ compr., glabros. Sépalas externas glabras, 2 superiores $1,0 \times 0,5 \mathrm{~mm}$, lanceoladas, soldadas no $1 / 4$ basal, ápice agudo, base subobtusa; 1 inferior $1,2 \times 0,5 \mathrm{~mm}$, oval, côncava, 2 glândulas basais, ápice obtuso, base obtusa; 2 alas 1,5-1,7×0,8-1,0 mm, obovais, glabras, ápice e base obtusos. Corola rósea a purpúrea, glabra, persistente no fruto; carena ca. 1,0 mm compr., ápice cristado, 4-lobulado, cuculo sulcado no dorso; pétalas laterais $1,5 \times 0,5 \mathrm{~mm}$, obovais, ápice obtuso, base cuneada. Bainha estaminal ca. 0,5-1,0 mm compr., glabra; 6 estames, anteras obovais. Ovário 1,0× $<0,5 \mathrm{~mm}$, suborbicular ou oval-elíptico; estilete uncinado; estigma globoso; cavidade pré-estigmática, em forma de coifa, oblíqua, com tufo de tricomas no ápice, sem apêndice cristado. Cápsula 1,0-1,5×1,0 mm, assimétrica, orbicular, sem glândulas cróceas ao longo do septo, ápice emarginado. Sementes $0,8 \times 0,5 \mathrm{~mm}$, piriformes, base arredondada, pubérulas, tricomas hialinos, não uncinados; sem apêndices.

De acordo com Marques (1988), Polygala sedoides é uma espécie provavelmente endêmica do Brasil, onde foi registrada para os Estados do Amazonas, Piauí, Maranhão, Ceará, Goiás e Mato Grosso. Na Paraíba, a espécie foi encontrada em remanescentes de Floresta Atlântica, ocorrendo em solos humosos, arenosos e alagados.

Material examinado: BRASIL. Paraíba: Conde, Praia de Tabatinga, VIII/1992, fl., O.T. Moura 787 (JPB); Mamanguape, Miripitanga, Sema II, VIII/1989, fl., fr., L.P. Felix \& E.S. Santana s.n. (EAN 5351); Capim Azul, VIII/1988, fl., fr., L.P. Felix \& C.A.B. Miranda s.n. (JPB).

10. Polygala spectabilis DC., Prodr. 1: 331. 1824. Fig. 84-93

Arbusto 0,4-2 m alt.; caule lenhoso, ramificado logo acima da base; ramos sublenhosos, pubérulos. Folhas alternas, membranáceas; pecíolo 2,0-4,0× 0,5 mm, cilíndrico, 2 glândulas opostas na base; lâminas 35,0-63,0×15,0-32,0 mm, lanceoladas a elípticas, pubérulas, ápice agudo a obtuso, emarginado (raro), base cuneada ou oblíqua. Racemos laxifloros, 2,5-1,2 cm compr., glabros, com glândulas opostas na raque e pedúnculo; bráctea central 1,5-2,0 $\mathrm{mm}$ compr., triangular-lanceolada, ápice ligulado. Pedicelo ca. 6,0 mm compr., piloso, pêndulo no fruto. Sépalas externas glabras, ciliadas; 2 superiores 3,0-4,0×
4,0-5,0 mm, oblatas, levemente côncavas, livres entre si, ápice obtuso-arredondado; 1 inferior, 5,0×5,5 mm, oblata, côncava, ápice obtuso-arredondado; 2 alas 12,0-14,0×0,9-11,0 mm, ovais, glabras, ápice ciliado, obtuso, base obtusa. Corola branca, rajada de amarelo e roxo, glabra; carena $12,0-13,0 \times 80,0 \mathrm{~mm}$, ápice inteiro, emarginado, cuculo não sulcado no dorso; pétalas laterais 11,0-13,0×40,0 mm, oblongas, ápice curvado. Bainha estaminal ca. 11,0 mm compr., glabra; 8 estames, anteras oblongas. Ovário 1,5×1,0-1,5 mm compr., oblongo; estilete uncinado ou geniculado; estigma cimbiforme, glabro, sem cavidade préestigmática. Cápsula 17,0×16,0 mm, elíptica ou oval, sem glândulas cróceas ao longo do septo, ápice obtusoemarginado. Sementes 3,0-5,0 mm, campanuladas, verrucosas, pilosas, tricomas não uncinados; carúnculas longas, atingindo 1/2-2/3 do comprimento da semente.

Polygala spectabilis é uma espécie neotropical, encontrada no Peru (Brako \& Zarucchi 1993), Guiana Francesa (Jacobs-Brouwer 2002) e no Brasil, onde foi referida para o Acre, Amapá, Amazonas, Pará e Rio de Janeiro (Marques 1979). Na Paraíba, foi encontrada em áreas de Floresta Atlântica e Brejos de altitude, habitando solos humosos e afloramentos rochosos.

Material examinado: BRASIL. Paraíba: João Pessoa, Campus I, UFPB, III, 1992, fl., fr., M.S. Pereira 3 (JPB); II/2000, fl., M.F. Agra \& Góis 5566 (JPB); 757'S, 3453'W, II/1996, fl., M.F. Agra 3639 (JPB); Rio Tinto, Mata do Maracujá, Sema III, V/1990, fl., fr., L.P. Félix \& E.S. Santana 3044 (JPB); Maturéia, Pico do Jabre, IV/2002, fl., fr., M.F. Agra 5776 (JPB); Santa Rita, Tibirizinho, Usina São João, II/1992, fl., M.F. Agra \& Góis 1401 (JPB).

11. Polygala violacea Aubl., Hist. Pl. Guiane 2: 735, t. 294.1775.

Fig. 94-102

Erva 14-32 cm alt.; caule e ramos pilosos, tricomas adpressos, hialinos e curtos, falciformes. Folhas alternas, membranáceas; pecíolo 2,0×1,0 mm, cilíndrico a subanguloso, pubérulo; lâminas 21,0-42,0× 7,0-19,0 mm, estreitamente lanceoladas a largamente lanceoladas, margens ciliadas, glabras na face adaxial, pubérulas na face abaxial, ápice agudo, base cuneada a obtusa. Racemos espiciformes, laxifloros, 2,0-1,5 cm compr., raque e pedúnculo pilosos, tricomas hialinos; bráctea central 1,5×0,5 mm, lanceolada, ápice subulado, margem ciliada. Pedicelo 1,0-2,0 mm compr., pubérulo, pêndulo no fruto. Sépalas externas glabras, glandulosociliadas; 2 superiores 1,5-2,0×1,0-2,0 mm, soldadas 

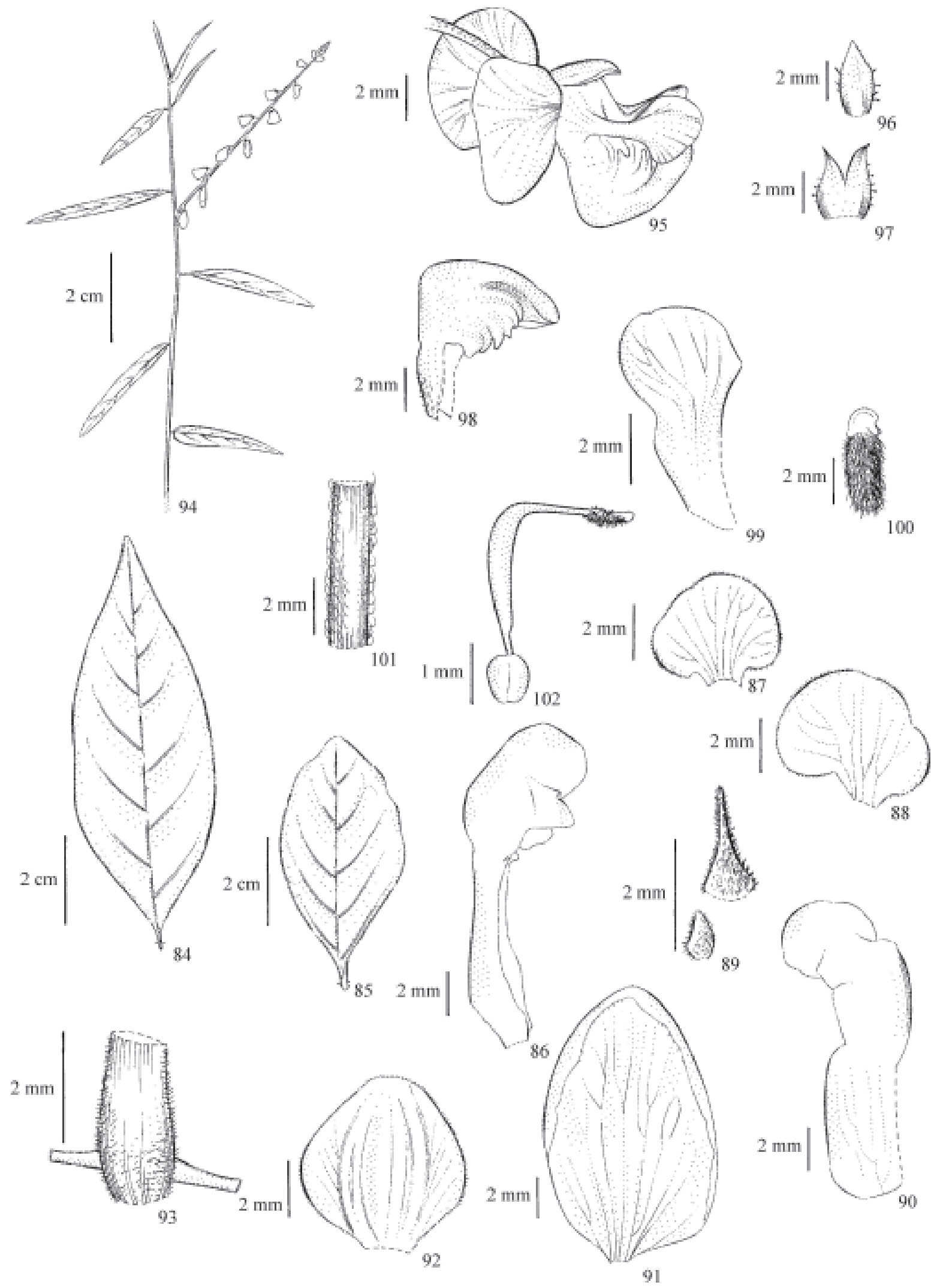

Figuras 84-93. Polygala spectabilis DC. (Agra 3639): 84-85. Folhas. 86. Carena. 87-88. Sépalas externas superiores. 89. Bráctea e bractéola. 90. Pétala lateral. 91. Ala isolada. 92. Sépala externa inferior. 93. Glândulas opostas na base do pecíolo. Figuras 94-102. P. violacea Aubl. (Agra \& Coelho 6659): 94. Ramo. 95. Flor. 96. Sépala externa inferior. 97. Sépalas externas superiores. 98. Carena. 99. Pétala lateral. 100. Semente. 101. Indumento do caule. 102. Gineceu. 
parcialmente, levemente côncavas, ápice agudo; 1 inferior 2,0-2,5×1,0 mm, lanceolada, côncava, ápice agudo, base truncada; 2 alas 4,0-4,5×2,5-3,0 mm, obovais ou suborbiculares, glabras, ápice obtuso-arredondado, base cuneada. Corola rósea a purpúrea; carena 3,0-4,5 mm compr., glabra internamente, ápice inteiro, emarginado, cuculo não sulcado no dorso; pétalas laterais 3,5-4,0 mm compr., espatulada, pilosa, tricomas patentes, hialinos. Bainha estaminal 3,0-4,5 mm compr., pilosa, tricomas similares aos das pétalas laterais; 8 estames, anteras obovais ou oblongas. Ovário 1,0-1,5×1,0 mm, retangular ou elíptico-ovado; estilete uncinado ou geniculado; estigma subgloboso, com tufo de tricomas na porção inferior; sem cavidade préestigmática. Cápsula ca. 3,5×2,5-3,0 mm, elíptica a oval, sem glândulas cróceas ao longo do septo, ápice emarginado, base obtusa. Sementes 2,5-3,0×1,0 mm, oblongas, sub-quadrangulares na base, seríceas, tricomas adpressos, não uncinados; carúncula com dois apêndices córneos na base.

De acordo com Marques (1979), Polygala violacea é uma espécie neotropical, encontrada na América Central, Caribe e América do Sul. No Brasil, foi registrada para todas as regiões, exceto para o sul. Na Paraíba, a espécie foi encontrada em áreas de Floresta Atlântica e Caatinga, ocorrendo em solos argilosos, humosos, arenosos, pedregosos e em afloramentos rochosos, como também em terrenos abandonados e campos de cultivo.

Material examinado: BRASIL. Paraíba: Conde, Praia de Jacumã, V/1991, fl., fr., O.T. Moura 610 (JPB); Mamanguape, VIII/1988, fl., fr., L.P. Félix \& C.A.B. Miranda s.n. (JPB 8445); Areia, II/1992, fl., fr., M.F. Agra \& M.R.V. Barbosa 1335 (JPB); Cabaceiras, III/1992, fl., fr., V.L. Nascimento \& C.F. Martins 59 (JPB); estrada para Boa Vista, VI/1994, fl., fr., M.F. Agra et al. 3019 (JPB); Santa Luzia, V/2002, fl., fr., M.F. Agra \& R.A. Pontes 5848 (JPB); São João do Cariri, IV/1994, fl., fr., M.F. Agra 3001 (JPB); Santa Rita, IX/2005, fl., fr., M.F. Agra \& V. Coelho 6659 (JPB); IX/2005, fl., fr., M.F. Agra \& V. Coelho 6660 (JPB); São José da Mata, Faz. Pedro da Costa Agra, 7²6'S, 3552'W, VI/1996, fl., M.F. Agra et al. 3752 (JPB); VI/1996, fl., M.F. Agra et al. 3771 (JPB).

\section{Agradecimentos}

Os autores agradecem ao Conselho Nacional de Desenvolvimento Científico e Tecnológico (CNPq), pelas bolsas concedidas; aos curadores dos herbários
EAN, JPB e IPA, pelo empréstimo do material examinado e livre acesso às suas coleções; ao Dr. Marccus Alves, Dra. Maria Regina Barbosa e Dra. Iracema Loiola, pela revisão do manuscrito e sugestões apresentadas; aos colegas José Floriano, pela contribuição com a bibliografia e sugestões, Ricardo A. Pontes e Emerson A. Rocha, pelo apoio às coletas; à Dulce G. Oliveira, pelo apoio técnico.

\section{Referências bibliográficas}

Adolfo, M.H. 1966. Nómina de las plantas recolectadas en el valle de Cochabamba 2: 17-86.

Agra, M.F.; Barbosa, M.R.V. \& Stevens, W.D. 2004. Levantamento florístico preliminar do Pico do Jabre, Paraíba, Brasil. Pp. 123-138. In: K.C. Porto; J.J.P. Cabral \& M. Tabarelli (eds.). Brejos de altitude em Pernambuco e Paraíba: história natural, ecologia e conservação. Brasília, Ministério do Meio Ambiente.

APG II. 2003. An update of the Angiosperme Phylogeny Group classification for the orders and families of flowering plants. Botanical Journal of the Linnean Society 141: 399-436.

Bennett, A.W. 1874. Polygalaceae. Pp. 1-30, est.1-30. In: C.F.P Martius; A.W. Eichler \& I. Urban (eds.). Flora Brasiliensis 13. München.

Barbosa, M.R.V.; Lima, R.B.; Agra, M.F.; Cunha, J.P. \& Pessoa, M.C.R. 2005. Vegetação e flora fanerogâmica do Curimataú, Paraíba. Pp. 121-128. In: F.S. Araújo; M.J.N. Rodal \& M.R.V. Barbosa (orgs.). Análise das variações da biodiversidade do bioma Caatinga. Brasília, Ministério do Meio Ambiente.

Brako, L. \& Zarucchi, J.L. 1993. Catalogue of the Flowering Plants and Gymnosperms of Peru. Monographs in Systematic Botany from the Missouri Botanical Garden 45: 1-1286.

Brummitt, R.K. \& Powell, C.E. 1992. Authors of plant names. Kew, Royal Botanic Gardens.

Campos, R.O.P.; Santos, A.R.S.; Vaz, Z.R.; Pinheiro, T.R.; Pizzolatti, M.G.; Filho, V.C.; Monache, F.D.; Yunes, R.A. \& Calixto, J.B. 1997 Antinociceptive properties of the hydroalcoholic extract and preliminary study of a xanthone isolated from Polygala cyparissias (Polygalaceae). Life Sciences 61: 1619-1624.

Chodat, R.H. 1893. Monographia Polygalacearum. Mémoires de la Société de Physique et d'Histoire Naturelle de Genève 31: 1-500.

Cronquist, A. 1988. The evolution and classification of flowering plants. $2^{\text {nd }}$ ed. New York, The New York Botanical Garden, Bronx.

Estradaa, A.; Katselisb, G.S.; Laarvelda, B. \& Barl, B. 2000. Isolation and evaluation of immunological adjuvant activities of saponins from Polygala senega L. Comparative Immunology, Microbiology \& Infectious Diseases 23: 27-43. 
Eriksen, B. 1993. Phylogeny of the Polygalaceae and its taxonomic implications. Plant Systematics and Evolution 186: $33-55$.

Foster, R.C. 1958. A catalogue of the ferns and flowering plants of Bolivia. Contributions from the Gray Herbarium of Harvard University 184: 1-223.

Furness, S.H. \& Stafford, P.J. 1995. The Northwest European Pollen Flora, 55 Polygalaceae. Review of Palaeobotany and Palynology 88: 61-82.

Hamburger, M.; Stoeckli-Evans, H. \& Hostettmann, K. 1984. A new pyranocoumarin diester from Polygala paniculata L. Helvetica Chimica Acta 67: 1729-1733.

Hamburger, M.; Gupta, M. \& Hostettmann, K. 1985. Coumarins from Polygala paniculata. Planta Medica 51: $215-216$.

Hutchinson, J. 1964. The genera of flowering plants, part 1. Oxford, Clarendon Press.

Jacobs-Bronwer, A. 2002. Polygalaceae (MilkWort Family). Pp. 585-589. In: S.A. Mori; G. Cremers; C.A. Gracie; J.J. de Grenville; V. Heald; M. Hoff \& J.D. Mitchell (eds.). Guide to vascular plants of Central French Guiane Memories of The New York Botanical Garden. The New York Botanical Garden, Press.

Jiang, Y. \& Tu, Peng-Fei. 2002. Xanthone O-glycosides from Polygala tenuifolia. Phytochemistry 60: 813-816.

Lüdtke, R. \& Miotto, S.T.S. 2004. O gênero Polygala L. (Polygalaceae) no Rio Grande do Sul, Brasil. Revista Brasileira de Biociências 2: 49-102.

Marques, M.C.M. 1979. Revisão das espécies do gênero Polygala L. (Polygalaceae) do Estado do Rio de Janeiro. Rodriguesia 48: 69-339, est. 1-84.

Marques, M.C.M. 1980. Revisão das espécies do gênero Bredemeyera Will. (Polygalaceae) do Brasil. Rodriguésia 54: 269-321.

Marques, M.C.M. 1984a. Polígalas do Brasil I. Seção Acanthocladus (K1. ex Hassk.) Chod. do gênero Polygala L. (Polygalaceae). Rodriguésia 36: 3-12.

Marques, M.C.M. 1984b. Polígalas do Brasil II. Seção Gymnospora Chod. do gênero Polygala L. (Polygalaceae). Rodriguésia 36: 31-34.

Marques, M.C.M. 1984c. Polygala grazielae M. C. Marques uma nova espécie de Polygala L. para Mato Grosso do Sul. Rodriguésia 36: 17-20.

Marques, M.C.M. 1988. Polígalas do Brasil V. Seção Polygala (Polygalaceae) Arquivos do Jardim Botânico do Rio de Janeiro 29: 1-114.

Marques, M.C.M. 1989. Monnina Ruiz et Pavon (Polygalaceae) no Brasil. Rodriguésia 67: 3-33.

Marques, M.C.M. 1995. Polygalaceae. Pp. 534-541. In: B.L. Stannard (ed.). Flora of the Pico das Almas, Chapada Diamantina-Bahia, Brasil. Kew, Royal Botanic Garden.

Marques, M.C.M. 1996. Securidaca L. (Polygalaceae) do Brasil. Arquivo do Jardim Botânico do Rio de Janeiro 34: 7-144.

Marques, M.C.M. 1997. Flora do Estado do Rio de Janeiro, Polygalaceae. Albertoa 4: 130-199.
Marques, M.C.M. 2003. Polygala bevilacquai Marques (Polygalaceae), uma nova espécie endêmica de São Paulo, Brasil. Hoehnea 30: 213-215.

Marques, M.C.M. \& Gomes, K. 2002. Polygalaceae. Pp. 229-259. In: M.G.L.Wanderley; G.J.Sheperd, A.M. Giulietti; T.S'A. Melhem; V. Bittrich \& C. Kameyama (eds.). Flora Fanerogâmica do Estado de São Paulo. v. 2. São Paulo, Editora Hucitec.

Marques, M.C.M. \& Guimarães, E.F. 2003. Espécie e variedades novas de Polygala L. (Polygalaceae) do Brasil. Bradea 9: 45-50.

Marques, M.C.M. \& Pastore, J.F.B. 2006. Duas espécies novas de Polygala L. (Polygalaceae) para o Brasil. Rodriguésia 57: 99-102.

Matos, F.J.A. 2000. Plantas Medicinais: guia de seleção e emprego de plantas usadas em fitoterapia no nordeste do Brasil. 2 ed. Fortaleza, Imprensa Universitária - UFC.

Miranda, E.B. 2006. Polygalaceae. Pp. 132-133. In: M.R.V. Barbosa; C. Sothers; S. Mayo; C.F.L. Gamarra-Rojas \& A.C. Mesquita (orgs.). Checklist das plantas no nordeste brasileiro: Angiospermas e Gymnospermas. Brasília, Ministério da Ciência e Tecnologia.

Nagai, T.; Suzuki, Y.; Kiyohara, H.; Susa, E.; Kato, T.; Nagamine, T.; Hagiwara, Y.; Tamura, Shin-ichi; Yabe, T.; Aizawa, C. \& Yamadaa, H. 2001. Onjisaponins, from the root of Polygala tenuifolia Willdenow, as effective adjuvants for nasal influenza and diphtheria-pertussistetanus vaccines. Vaccine 19: 4824-4834.

Nurit, K.; Agra, M.F.; Basílio, I.J.L.D. \& Baracho, G.S. 2005. Flora da Paraíba, Brasil: Loganiaceae. Acta Botanica Brasilica 19: 407-416.

Paiva, J.A.R. 1998. Polygalarum Africanum et madagascariensium prodromus atque gerontogaei generis Heterosamara Kuntze, a genere Polygala segregati et a nobis denuo recepti, synopsis monographica. Fontqueria 50: 1-346.

Persson, C. 2001. Phylogenetic ralationships in Polygalaceae based on plastid DNA sequences from the $\operatorname{trn} \mathrm{L}-\mathrm{F}$ region. Taxon 50: 763-779.

Persson, C. 2003. Polygalaceae. Pp. 306-308. In: N. Smith; S.A. Mori; A. Henderson; D.W. Stevenscon \& S.V. Heald (eds.). Flowerings plants of the Neotropics. New Jersey, Princenton University Press.

Pinheiro, T.R.; Cechinel Filho, V.; Santos, A.R.S.; Calixto, J.B.; Monache, F.D.; Pizzolatti, M.G. \& Yunes, R.A. 1998. Three xanthones from Polygala cyparissias. Phytochemistry 48: 725-728.

Pizzolatti, M.G.; Luciano, C. \& Monache, F.D. 2000. Styryl and dihydrostyry 1-2-pyrones derivatives from Polygala sabulosa. Phytochemistry 55: 819-822.

Pizzolatti, M.G.; Koga, A.H; Grisar, E.C. \& Steindel, M. 2002a. Trypanocidal activity of extracts from Brazilian Atlantic Rain Forest plant species. Phytomedicine 9: 422-426. 
Pizzolatti, M.G.; Cristiano, R.; Monache, F.D. \& Branco, A. 2002b. Artefatos cumarínicos isolados de Polygala paniculata (Polygalaceae). Revista Brasileira de Farmacognosia 12: 21-26.

Pizzolatti, M.G.; Cunha, A.; Pereira, W.S. \& Monache, F.D. 2004. A new styryl-2-pyrone derivative from Polygala sabulosa (Polygalaceae). Biochemical Systematics and Ecology 32: 603-606.

Rizzini, C.T. 1977. Sistematização terminológica da folha. Rodriguésia 29: 103-125.

Shin, Eun-Joo; Oh, Ki-Wan; Kim, Kee-Won; Kwon, Y.S.; Jhoo, J.H.; Jhoo, Wang-Kee; Cha, Joo-Young; Lim, Y.K.; Kim, I.S. \& Kim, Hyoung-Chun. 2004. Attenuation of cocaineinduced conditioned place preference by Polygala tenuifolia root extract. Life Sciences 75: 2751-2764.
Martins, L. \& Marques, M.C.M. 1999. Polygalaceae. Pp. 516-519. In: J.E.L.S. Ribeiro; M.J.G. Hopkins; A. Vicentini; C.A. Sothers; M.A.S. Costa; J.M. Brito; M.A.D. Souza; L.H.P. Martins; L.G. Lohmann; P.A.C.L. Assunção; E.C. Pereira; C.F. Silva; M.R. Mesquita \& L.C. Procópio (orgs.). Flora da reserva Ducke: guia de identificação das plantas vasculares de uma floresta de terra firme na Amazônia central. Manaus, INPA.

$\mathrm{W}^{3}$ TROPICOS - VAST specimen data base. Disponivel em: <http://mobot.mobot.org/cgi-bin/search_vast >. (Acessado em: 15/junho/2006).

Wurdack, J.J. \& Smith, L.B. 1971. Flora Ilustrada Catarinense (Polygalaceae). Itajaí. Tipografia e Livraria Blumenauense S.A. 